\title{
POMIARY WYSOKOŚCI I PRĘDKOŚCI LOTU MAŁEGO SAMOLOTU BEZZAŁOGOWEGO Z WYKORZYSTANIEM RUREK PRANDTLA
}

\begin{abstract}
Niezawodne pomiary prędkości powietrza opływającego skrzydła samolotu oraz wysokości na jakiej znajduje się statek powietrzny są niezbędne do sterowania samolotem bezzałogowym. Z uwagi na konieczność stosowania procesów automatycznej stabilizacji lotu, bezzałogowe samoloty wymagają niskiego opóźnienia toru pomiarowego. Do pomiaru tych wielkości zbudowano system oparty na dwóch torach pomiarowych wykorzystujących rurkę Prandtla. Niniejszy artykuł opisuje efekty projektu badawczego prowadzonego w Studenckim Kole Naukowym Elektroników Politechniki Rzeszowskiej, poszukującego niezawodnego i szybkiego rozwiązania o podwyższonej dokładności.
\end{abstract}

Słowa kluczowe: rurka spiętrzeniowa, ciśnienie statyczne, ciśnienie dynamiczne, prędkość przepływu gazu

\section{Wprowadzenie}

Ze względu na swoje wymiary i niewielką masę małe samoloty bezzałogowe są obiektami wymagającymi szybkiego sterowania. Układ automatycznej stabilizacji lotu małego statku powietrznego do swej poprawnej pracy wymaga dostarczenia pomiarów o małym opóźnieniu czasowym oraz dużej częstotliwości próbkowania [1]. Założenia te wykluczają stosowanie w torze pomiarowym, w celu eliminacji zakłóceń, filtrów dolnoprzepustowych o dużej stałej czasowej. Zastosowanie w prezentowanym rozwiązaniu dwóch torów pomiarowych, przetwarzających sygnał z oddalonych od siebie przetworników, nie tylko zapewnia redundancję pomiaru, ale także znaczące zmniejszenie zakłóceń bez wprowadzania niekorzystnego opóźnienia. Zaprezentowano także, opracowany w naszym ze-

\footnotetext{
1 Autor do korespondencji: Mirosław Sobaszek, Politechnika Rzeszowska, Wydział Elektrotechniki i Informatyki, Wincentego Pola 2, 35-959 Rzeszów, tel. (17) 743-22-48, email: somirek@prz.edu.pl

${ }^{2}$ Krzysztof Milewski, Politechnika Rzeszowska, Wydział Elektrotechniki i Informatyki, Wincentego Pola 2, 35-959 Rzeszów, tel. 514556979, email: 137850@ stud.prz.edu.pl
} 
spole, tor przetwarzania sygnału pomiarowego, zrealizowany w stosunkowo tanim, małym, lekkim i energooszczędnym układzie o niskich szumach własnych.

\section{Zasada pomiaru}

Do pomiarów wysokości i prędkości lotu samolotu powszechnie wykorzystuje się wyprowadzoną na zewnątrz płatowca sondę zwaną rurką Prandtla [2], pokazaną na rys. 1, która jest połączeniem sondy ciśnienia statycznego z rurką Pitota, służącą do pomiaru ciśnienia naporu powietrza na wlot rurki.

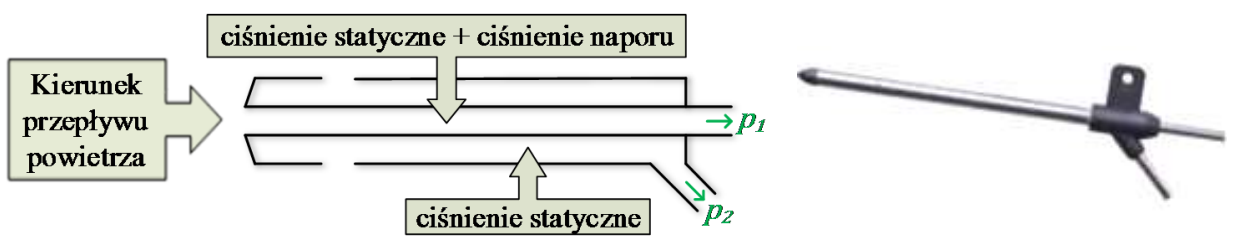

Rys. 1. Budowa rurki Prandtla

Fig. 1. Construction of the Prandtl tube

Względną wysokość samolotu określa się na podstawie pomiarów ciśnienia atmosferycznego na lotnisku o znanej wysokości n.p.m. i ciśnienia statycznego zmierzonego przez układ umieszczony na pokładzie samolotu, z wykorzystaniem wzoru barometrycznego:

$$
h \approx-\ln \left(\frac{p}{p_{0}}\right) \cdot \frac{R T}{\mu g},
$$

gdzie: $p_{0}$ - ciśnienie atmosferyczne na poziomie odniesienia [Pa],

$\mu$ - masa molowa powietrza $[\mathrm{kg} / \mathrm{mol}]$,

$g$ - przyspieszenie ziemskie $\left[\mathrm{m} / \mathrm{s}^{2}\right]$

$R$ - stała gazowa $[\mathrm{J} /(\mathrm{mol} \cdot \mathrm{K})]$,

$T$ - temperatura powietrza $[\mathrm{K}]$.

Na podstawie pomiaru ciśnień: naporu (z rurki wewnętrznej) oraz statycznego (z rurki zewnętrznej) można obliczyć prędkość powietrza wykorzystując wzór:

$$
v \approx \sqrt{2 \cdot \frac{p_{1}-p_{2}}{\rho}},
$$

gdzie: $p_{1}-$ ciśnienie naporu $[\mathrm{Pa}]$,

$p_{2}$ - ciśnienie statyczne[Pa], 
$\left(p_{1}-p_{2}\right)$ - ciśnienie spiętrzenia[Pa],

$\rho-$ gęstość powietrza $\left[\mathrm{kg} / \mathrm{m}^{2}\right]$.

\section{Układ pomiarowy}

\subsection{Budowa układu}

Układ pomiarowy składa się z trzech elementów: jednego centralnego mikrokomputera oraz dwóch podłączonych do niego poprzez magistralę I2C modułów pomiarowych (po jednym module pomiarowym na każdym skrzydle samolotu). Widok 3D modułu pomiarowego pokazano na rys. 2, natomiast schemat blokowy całego układu został przedstawiony na rys. 5 .

a)

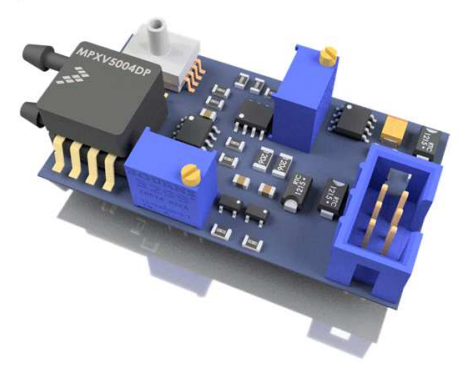

b)

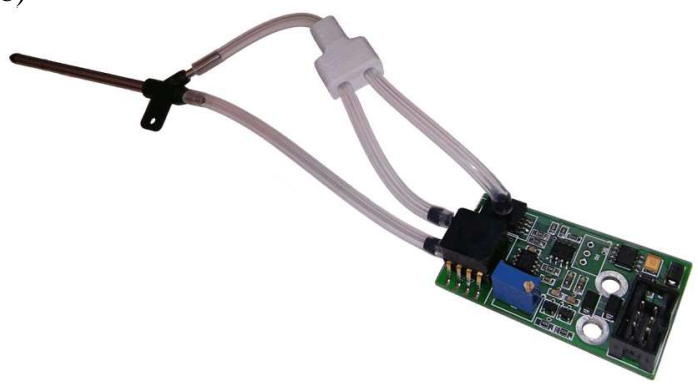

Rys. 2. Moduł pomiarowy: a) model 3D, b) realizacja

Fig. 2. Measurement module: a) 3D model, b) real photo

Każdy moduł pomiarowy zawiera przetworniki ciśnień: statycznego i spiętrzenia, analogowe układy kondycjonujące sygnały z przetworników ciśnień i przetworniki analogowo-cyfrowe. Odebrane przez mikrokomputer sygnały cyfrowe są następnie przetwarzane w celu dostosowania ich parametrów do potrzeb układu automatycznej stabilizacji lotu, obliczane są także prędkość i względna wysokość lotu samolotu. Układ centralnego mikrokomputera samolotu wyposażony jest $\mathrm{w}$ interfejs umożliwiający przesyłanie wybranego strumienia danych z systemu wbudowanego do komputera PC, co ułatwia kalibrację i weryfikację poprawności działania całego systemu pomiarowego.

\subsection{Pomiar ciśnienia statycznego}

Na rys. 3 pokazano wstępny tor przetwarzania sygnału pomiarowego ciśnienia statycznego. Cały system pomiarowy zawiera dwa takie tory - po jednym w każdym module pomiarowym. 


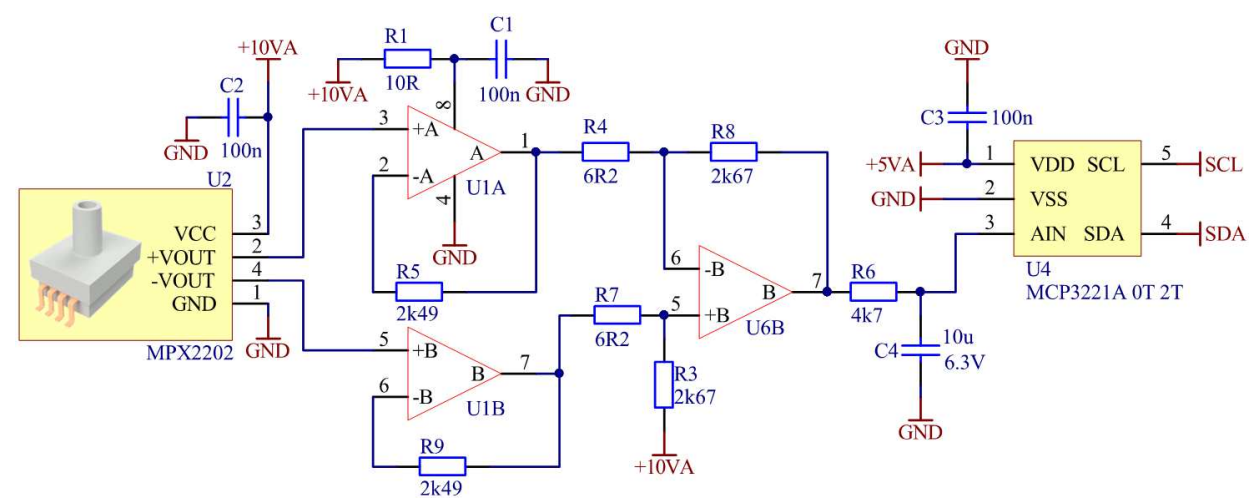

Rys. 3. Układ do pomiaru ciśnienia statycznego

Fig. 3. Static pressure measuring circuit

Do pomiaru ciśnienia statycznego, doprowadzonego z zewnętrznej komory rurki Prandtla, wykorzystano przetwornik ciśnienia absolutnego MPX2202. Jest to kompensowany termicznie piezoelektryczny przetwornik ciśnienia o zakresie pomiarowym od 0 do $200 \mathrm{kPa}$ i czułości $0,2 \mathrm{mV} / \mathrm{kPa}$. Ze względu na dość dużą i zmienną w funkcji poziomu sygnału rezystancję wyjściową przetwornika ciśnienia absolutnego (wg noty katalogowej zmienia się ona od $1,4 \mathrm{k} \Omega$ do $3 \mathrm{k} \Omega$ ), napięcia wyjściowe są buforowane wtórnikami napięciowymi U1A i U1, dzięki czemu rezystancje wyjściowe przetwornika nie będą (odpowiednio w sumie z R4 i R7) wpływać na wzmocnienie wzmacniacza różnicowego. Wzmacniacz różnicowy U6B odwraca fazę i wzmacnia sygnał różnicowy tak, aby zakres pomiarowy przetwornika ADC pozwalał na pomiar wysokości w przybliżonym zakresie od 0 do około 5000 m n.p.m. (Wysokości 0 m n.p.m. odpowiada wartość sygnału równa 3,3 V na wejściu przetwornika ADC. Napięcie to zmniejsza się wraz ze wzrostem wysokości). Sygnał przed podaniem na przetwornik ADC (zrealizowany w układzie U4) jest filtrowany dolnoprzepustowym filtrem pierwszego rzędu.

\subsection{Pomiar ciśnienia spiętrzenia}

Na rys. 4 pokazano wstępny tor przetwarzania pomiaru ciśnienia spiętrzenia. Cały układ pomiarowy posiada dwa takie tory przetwarzania - po jednym na każdym module pomiarowym.

Pomiaru ciśnienia spiętrzenia dokonano z wykorzystaniem różnicowego przetwornika ciśnienia MPXV7002DP. Jest to kompensowany termicznie przetwornik ciśnienia różnicowego doprowadzonego z rurki Prandtla do dwóch zabudowanych w czujniku gniazd. Zakres pomiarowy wynosi od $-2 \mathrm{kPa}$ do $2 \mathrm{kPa}$, czułość $1 \mathrm{~V} / \mathrm{kPa}$, a offset napięcia wyjściowego czujnika jest równy połowie na- 
pięcia zasilania. Ze względu na fakt, że samolot w czasie lotu porusza się wyłącznie do przodu, różnica ciśnień podanych na czujnik jest zawsze dodatnia. Dlatego od sygnału z czujnika odjęto offset równy połowie napięcia zasilania (za pomocą wzmacniacza różnicowego U6A). Pozwala to na wykorzystanie całego zakresu przetwarzania przetwornika ADC. Otrzymany sygnał wzmocniono do wartości zapewniającej pomiar prędkości do około $120 \mathrm{~km} / \mathrm{h}$ i podano poprzez filtr antyaliasingowy pierwszego rzędu na wejście dwunastobitowego przetwornika ADC.

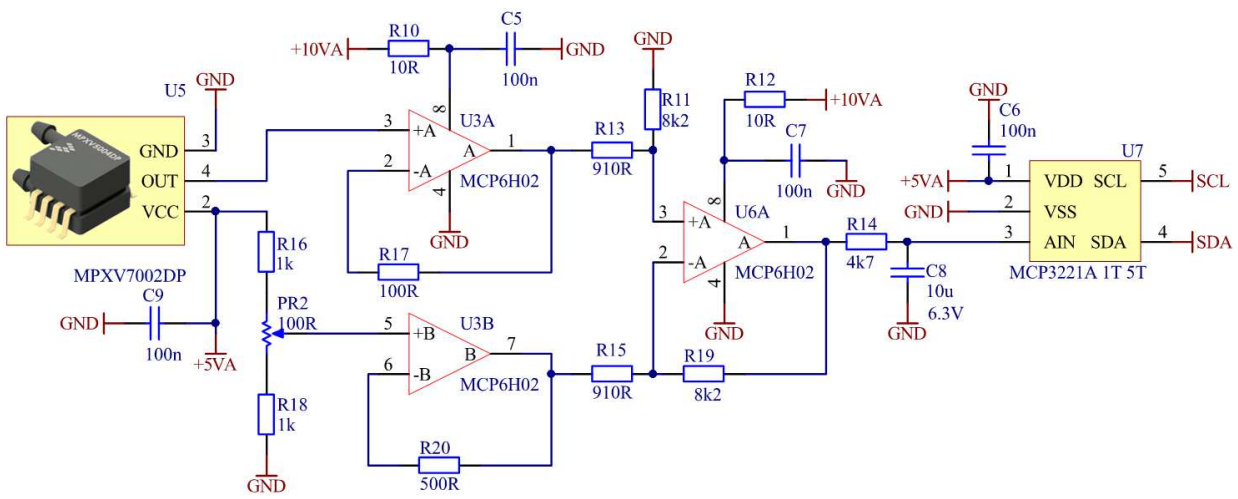

Rys. 4. Schemat układu kondycjonującego sygnał z przetwornika ciśnienia spiętrzenia (prędkość powietrza)

Fig. 4. Schematic of the signal conditioning circuit from the pressure transducer (airspeed)

\subsection{Przetwarzanie sygnałów $\mathrm{z}$ przetworników ciśnień $\mathrm{w}$ domenie cyfrowej}

Zastosowane w modułach pomiarowych przetworniki ADC - MCP3221A to wykorzystujące metodę przetwarzania analogowo-cyfrowego $\mathrm{z}$ sukcesywną aproksymacją układy o efektywnej wyjściowej rozdzielczości na poziomie $\mathrm{ENOB}_{\mathrm{ADC}}=11,85$ bitów i maksymalnej częstotliwości próbkowania 22 ksps.

Przetworniki ADC, mierzące sygnały z obydwóch rurek Prandtla, połączono za pośrednictwem magistral I2C do modułu komputera pokładowego samolotu, którego „sercem” jest mikroprocesor PIC32MX575F512H. Oprogramowanie mikrokontrolera zrealizowano jako zoptymalizowany do zastosowania w samolocie system czasu rzeczywistego, którego jeden z procesów służy do niezawodnej obsługi interfejsów przesyłu danych z czujników samolotu. Proces ten wyposażono w program sterownika magistrali I2C, który przeprowadza diagnostykę stanu magistrali dzięki sprzętowemu wsparciu producenta mikrokontrolera. 


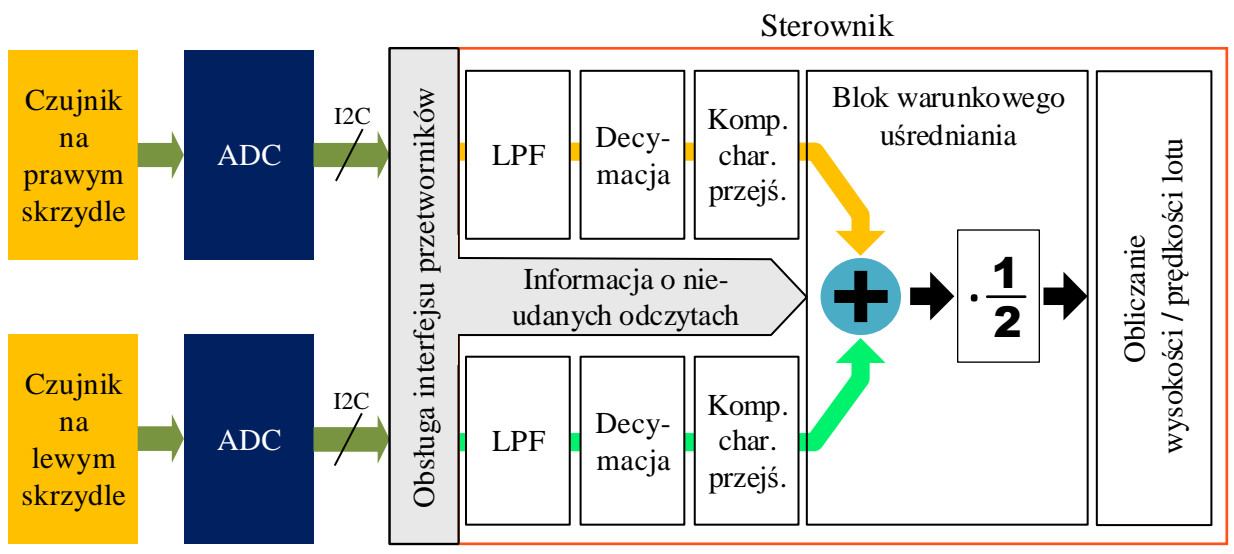

Rys. 5. Schemat blokowy systemu pomiarowego wysokości i prędkości lotu

Fig. 5. Block diagram of the altitude and flight speed measurement system

Sterownik, którego schemat blokowy przedstawiono na rys. 5, analizuje poprawność ramek danych odebranych z przetworników ADC oraz czasy pomiędzy pojawieniem się poszczególnych bajtów danych na magistrali $\mathrm{I} 2 \mathrm{C}$, porównując przebieg komunikacji ze standardem określonym przez producenta przetwornika ADC. W razie wykrycia błędów sterownik przeprowadza próbę odzyskania poprawnej łączności (wbudowany w mikrokontroler interfejs magistrali $\mathrm{I} 2 \mathrm{C}$ oraz protokół komunikacyjny przetwornika ADC pozwalają na wykonanie procedury resetującej). Sygnały ciśnień każdego z przetworników podawane są na wejście dolnoprzepustowego filtru uśredniającego, o szerokości okna zależnej od ilości poprawnie odebranych próbek. Obliczanie średniej odbywa się bezpośrednio przed wywołaniem funkcji algorytmu automatycznej stabilizacji lotu. Jest ono wyzwalane w momencie odebrania danych z inklinometru - w ten sposób zrealizowano decymację synchronizując częstotliwość wyjściową sygnałów prędkości i wysokości z częstotliwością sygnałów informujących o położeniu kątowym samolotu. Na podstawie danych, otrzymanych w procesie decymacji oraz zmierzonych w procesie kalibracji charakterystyk przetwarzania toru pomiarowego, oblicza się wartości wysokości i prędkości zmierzone za pomocą każdego z modułów pomiarowych. Poprawnie zmierzone wartości z prawego i lewego modułu pomiarowego uśrednia się i przekazuje do funkcji automatycznej stabilizacji lotu. Jeżeli w jednym z torów pomiarowych wykryto błędy połączenia lub przetwarzania analogowo-cyfrowego, sprawdza się, czy różnica otrzymanych wartości wysokości i/lub prędkości przekracza $5 \%$ wartości w stosunku do toru, w którym nie wykryto błędów. Wówczas dane te uznaje się za nieużyteczne i nie bierze się ich pod uwagę w czasie obliczeń. Jeśli dane $\mathrm{z}$ obydwu torów pomiarowych zawierają błędy, to na wyjściu układu pomiarowego wystawia się ostatnią 
poprawnie zmierzoną wartość. Częstotliwość próbkowania sygnału każdego z przetworników ciśnienia wynosi $1 \mathrm{kHz}$. Dzięki zastosowaniu dziesięciokrotnego nadpróbkowania oraz zdwojonego pomiaru, każdą wartość wyjściową prędkości i wysokości otrzymuje się na podstawie dwudziestu pomiarów, z których liczona jest średnia. Pozwala to na podniesienie dokładności przetwarzania analogowo-cyfrowego ponad czterokrotnie (zwiększono efektywną rozdzielczość o 2,16 bitów, co daje całkowitą efektywną rozdzielczość przetwarzania sygnałów ciśnienia na poziomie 14 bitów [3]).

\section{Pomiary}

\subsection{Kalibracja toru pomiaru ciśnienia statycznego (wysokość lotu)}

Do pomiaru wysokości i prędkości lotu samolotu, zgodnie z zależnościami (1) i (2), konieczne jest wyznaczenie charakterystyki przejściowej całego toru pomiarowego, od przetwornika ciśnienia do przetwornika analogowo-cyfrowego, a następne uwzględnienie zmierzonych zależności w obliczeniach.

Kalibrację toru pomiaru ciśnienia przeprowadzono w układzie przedstawionym na rys. 6 a.

a)

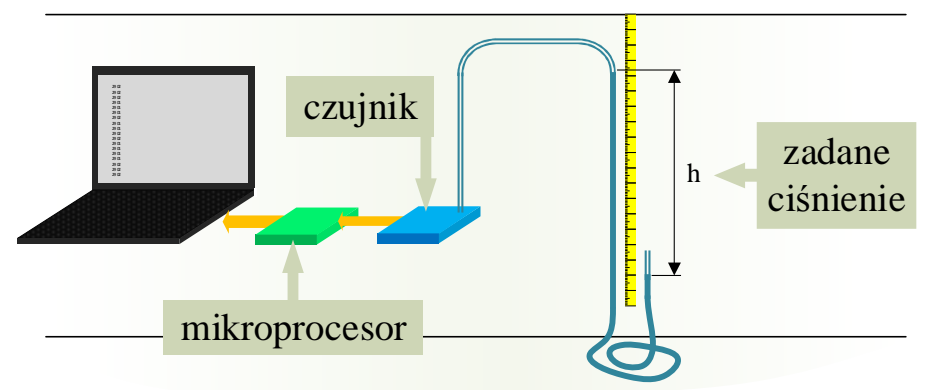

b)

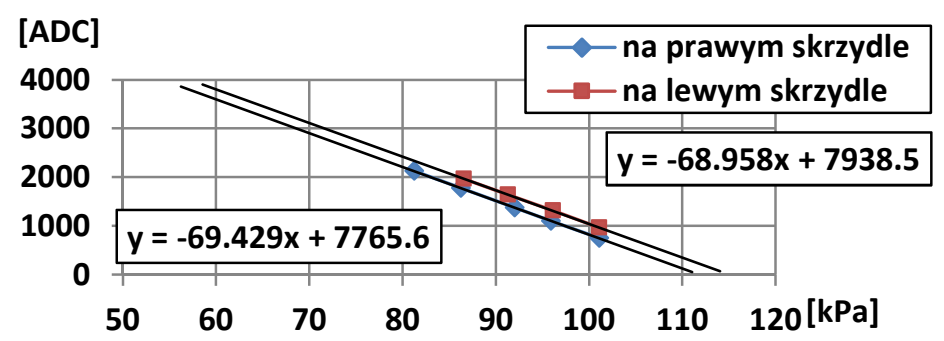

Rys. 6. Kalibracja toru pomiaru ciśnienia statycznego: a) stanowisko pomiarowe, b) wyniki pomiarów

Fig. 6. Calibration of the static pressure measurement path: a) measuring stand, b) measurement results 
Wartość ciśnienia na wejściu zadawano za pomocą rurki częściowo wypełnionej wodą, nastawiając odpowiednią wysokość słupa wody w rurce zgodnie ze wzorem:

$$
P=P_{a}-\rho g h,
$$

gdzie: $P_{a}$ - ciśnienie atmosferyczne $[\mathrm{Pa}]$,

$\rho$ - gęstość cieczy $\left[\mathrm{kg} / \mathrm{m}^{3}\right]$,

$g$ - przyspieszenie ziemskie $\left[\mathrm{m} / \mathrm{s}^{2}\right]$,

$h$ - wysokość słupa wody w rurce [m].

Zbadano fragment charakterystyki przejściowej przetwornika dla czterech różnych ciśnień wejściowych odpowiadających wysokości słupa wody $0 ; 0,5 ; 1$; $1,5 \mathrm{~m}$. Na podstawie pomiarów, $\mathrm{z}$ wykorzystaniem metody najmniejszych kwadratów, określono charakterystykę przejściową układu, pokazaną na rys. $6 \mathrm{~b}$.

\subsection{Kalibracja toru pomiaru prędkości lotu}

Pomiary charakterystyki przetwarzania układu do pomiaru prędkości lotu przeprowadzono wykorzystując jako urządzenie referencyjne przepływomierz CFM MASTER 8901 - w sposób pokazany na rys. 7. Ze względu na to, że średnice tuby pomiarowej przepływomierza i przewodu, w którym znajdowała się rurka Prandtla, były różne, wskazania przepływomierza przeskalowano proporcjonalnie do różnicy powierzchni przekrojów, w których mierzono prędkości.

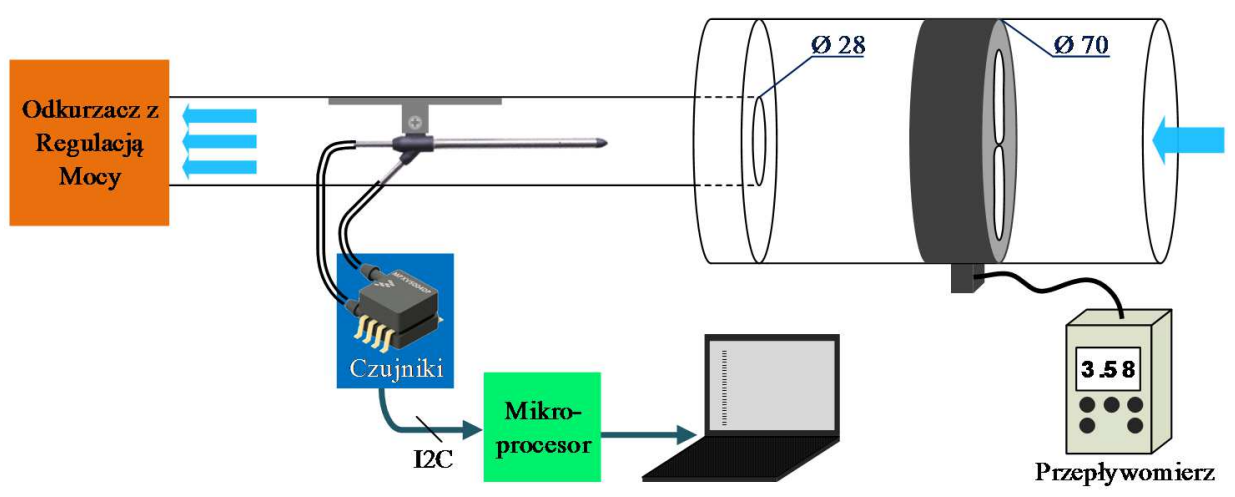

Rys. 7. Stanowisko do kalibracji toru pomiaru ciśnienia spiętrzenia (prędkość lotu)

Fig. 7. Stand for calibration of the pressure measurement path (airspeed)

Zmieniając moc odkurzacza wymuszającego przepływ powietrza opływającego rurkę Prandtla i porównując wyniki otrzymane z modułu pomiarowego do 
odczytów z przepływomierza, określono charakterystykę przetwarzania modułu pomiarowego pokazaną na rys. 8 .

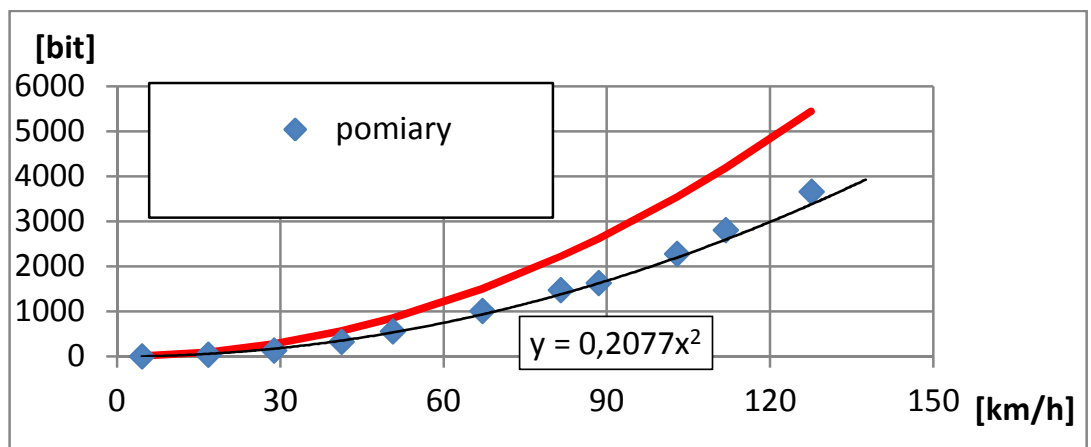

Rys. 8. Charakterystyka przetwarzania układu do pomiaru prędkości lotu

Fig. 8. Transfer characteristics of the airspeed measuring system

Na podstawie zależności (2) założono, że krzywa przetwarzania powinna być parabolą. Aproksymacji dokonano z wykorzystaniem metody najmniejszych kwadratów. Zmierzona charakterystyka okazała się znacząco różnić od wartości obliczonych ze wzoru teoretycznego, jednak ze względu na to, że producent deklaruje maksymalny błąd względny przetwornika na poziomie $6,26 \%$ oraz nieznany wpływ kształtu nasady rurki Prandtla na wyniki, przyjęto poprawność zmierzonej eksperymentalnie charakterystyki.

\subsection{Pomiar odchylenia standardowego sygnałów na wejściu i wyjściu toru cyfrowego przetwarzania danych z czujników pomiarowych}

W celu oszacowania poziomu szumu układu pomiarowego oraz wpływu bloku przetwarzania sygnałowego, zmierzono wielkości odchyleń standardowych sygnału wysokości i prędkości lotu. Badania odchylenia standardowego toru pomiarowego dokonano z zaczopowanymi portami przetworników ciśnienia. Analizie poddano sygnał cyfrowy pochodzący z pojedynczego przetwornika ciśnienia oraz sygnał pochodzący $\mathrm{z}$ wyjścia toru przetwarzania sygnału cyfrowego (będący wynikiem uśredniania nadpróbkowanych sygnałów z obu czujników). Analizowano sygnały o długości 10245 próbek. Wyniki analizy pomiarów pokazano w tab. 1. 
Tabela 1. Wyniki pomiarów odchylenia standardowego cyfrowych sygnałów z czujników

Table 1. The results of measurements of standard deviation of digital signals from sensors

\begin{tabular}{|c|c|c|}
\hline & $\begin{array}{c}\text { Odchylenie standardowe sygnału } \\
\text { z pojedynczego czujnika } \\
\text { (bez uśredniania) [bit] }\end{array}$ & $\begin{array}{c}\text { Odchylenie standardowe sygnału } \\
\text { uśrednionego z 64 kolejnych } \\
\text { próbek dwóch czujników [bit] }\end{array}$ \\
\hline Sygnał wysokości & 6,96 & 0,87 \\
\hline Sygnał prędkości & 2,13 & 1,56 \\
\hline
\end{tabular}

Pomiary wykonano z i bez zastosowania sześćdziesięcioczteropunktowego uśredniania sygnału (uśrednionego z wyjścia dwóch czujników). Dzięki uśrednianiu uzyskano niewielkie zmniejszenie odchylenia standardowego sygnału prędkości. Fakt ten jest wynikiem ulokowania znacznie większej gęstości szumu tego sygnału w zakresie małych częstotliwości, co uniemożliwia jego wyeliminowanie bez użycia dolnoprzepustowego filtru o dużej stałej czasowej, a więc wprowadzającego duże przesunięcie fazowe. Widmo sygnału szumu układu pomiaru prędkości pokazano na rys. 9.

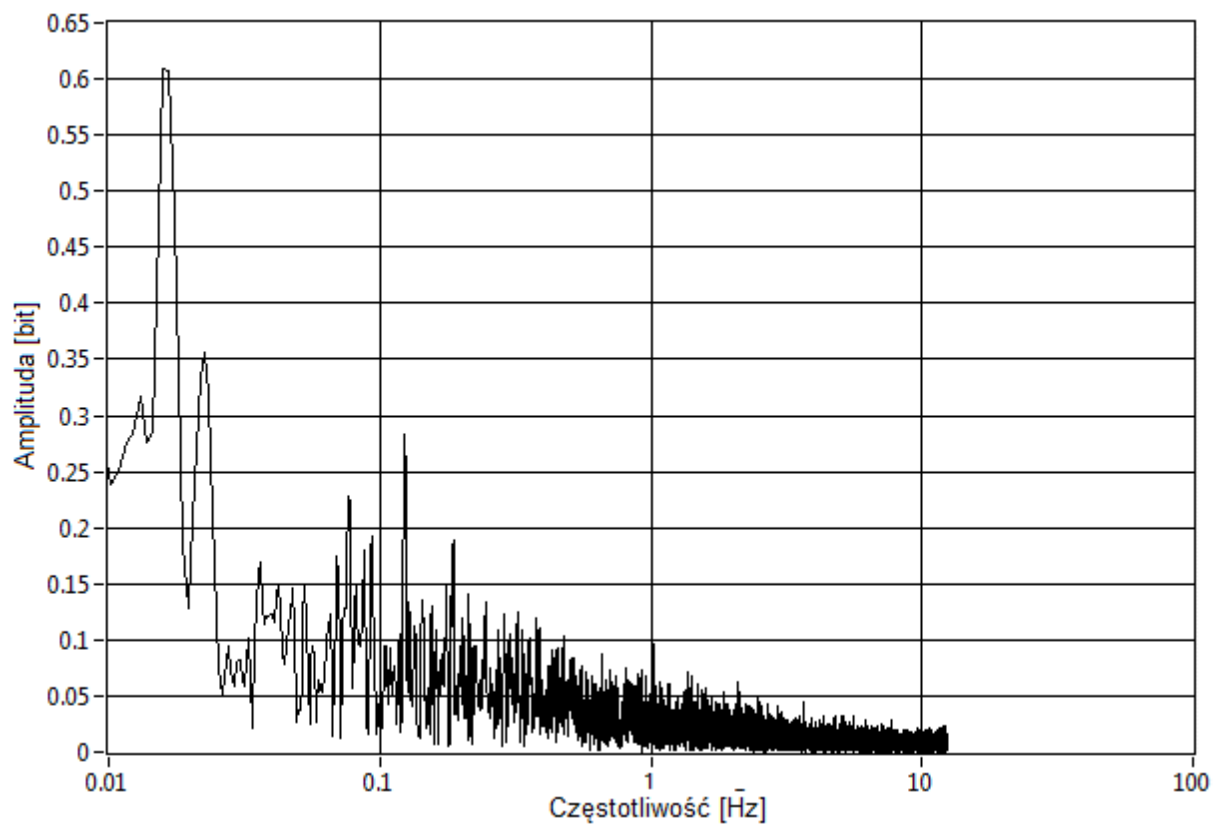

Rys. 9. Widmo sygnału szumu z różnicowego czujnika prędkości

Fig. 9. Noise spectrum from the airspeed sensor 


\section{Wnioski}

Poziom uzyskanego $\mathrm{w}$ systemie pomiarowym odchylenia standardowego sygnału prędkości jest wystarczający do zastosowania w samolocie bezzałogowym. Pewnym niedostatkiem systemu, zwłaszcza w czasie wykonywania manewrów startu i lądowania, jest mała dokładność pomiaru wysokości lotu. Z przeprowadzonych w rzeczywistych warunkach doświadczeń wiemy, że na stabilność pomiarów decydujący wpływ ma turbulentny charakter przepływu powietrza. W czasie występowania np. porywistego wiatru wskazanie wysokości lotu, może zmieniać się w rytm podmuchów (w zależności od ustawienia rurki Prandtla). Dlatego do określania wysokości lotu w czasie startu czy lądowania warto dodatkowo użyć czujników wykorzystujących wiązkę światła laserowego lub podczerwonego. Na szczególną uwagę zasługuje realizacja systemu zbierania i przetwarzania danych z przetworników zapewniająca podwyższoną niezawodność systemu pomiarowego, gdyż w przypadku usterki jednego z czujników poprawne pomiary są nadal przekazywane do funkcji realizującej automatyczne sterowanie samolotem - mają jedynie mniejszą dokładność. Ponadto gdy komunikacja, z którymś z przetworników ADC zostanie zawieszona, lub gdy prowadzona jest nieprawidłowo, na skutek np. zakłócenia napięcia zasilania - oprogramowanie sterownika stara się przywrócić poprawną komunikację. Proste testy odzyskania komunikacji po np. fizycznym rozłączeniu magistrali potwierdziły skuteczność działania opisanych zabezpieczeń.

\section{Literatura}

[1] Bociek Stanisław, Gruszecki Jan: Układy Sterowania Automatycznego Samolotem. Oficyna Wydawnicza Politechniki Rzeszowskiej, 1999. ISBN 83-7199-123-1

[2] Polak Zbigniew, Rypulak Andrzej: Awionika, Przyrządy i Systemy Pokładowe. Wyższa Szkoła Oficerska Sił Powietrznych, 2002. ISBN 83-912861-6-9

[3] Lyons G. Richard: Understanding Digital Signal Procesing. Addison- Wesley, 1999. ISBN 0-201-63467-8

\section{MEASUREMENT OF ALTITUDE AND AIRSPEED OF AN UNMANNED AIRCRAFT WITH THE USE OF PRANDTL TUBES}

\section{S u m m a r y}

Reliable measurements of the air velocity flowing around the wings of the aircraft and the altitude at which the aircraft is located are necessary for controlling the unmanned aircraft. Due to the need to use automatic flight stabilization processes, unmanned aircraft require a minimal delay in the measuring path. For correct measurement of these quantities, a system based on two measuring lines using backflow tubes was built. This article describes the effects of a research project 
carried out by the Student Scientific Group of Electronics at the Rzeszów University of Technology, who were seeking a reliable and quick solution with increased accuracy.

Keywords: backflow tubes, dynamic pressure, static pressure, gas flow rate

DOI: $10.7862 /$ re. 2020.7

Przestano do redakcji: czerwiec $2019 r$.

Przyjęto do druku: luty 2021 r. 